\title{
METODE PERENCANAAN STRATEGIS KINERJA SDM MENGGUNAKAN ANALISIS SWOT: ANALISIS DESKRIPTIF PADA PALANG MERAH INDONESIA (PMI)
}

\author{
IMPLEMENTATION OF HR PERFORMANCE ASSESSMENT EVALUATION \\ USING SWOT ANALYSIS: DESCRIPTIVE ANALYSIS ON THE INDONESIAN RED \\ CROSS (PMI)
}

Erwin Purwaningsih ${ }^{1}$

erwinpurwaningsih.ars@gmail.com ${ }^{1}$

\author{
Departemen Administrasi Rumah Sakit, Sekolah Tinggi Ilmu Kesehatan \\ Mutiara Mahakam
}

\begin{abstract}
ABSTRAK
PMI merupakan organisasi kemanusiaan yang mempunyai empat tugas pokok yakni, kesiapsiagaan bantuan dan penanggulangan bencana, pelatihan pertolongan pertama untuk sukarelawan, pelayanan kesehatan dan kesejahteraan masyarakat, pelayanan transfusi darah. Metode: Penelitian ini merupakan penelitian deskriptif analitik dengan desain non eksperimental (Cross Sectional). Sesuai dengan tujuan penelitian, subjek dan populasi penelitian peneliti mengambil gambaran garis besar salah satu organisasi kesehatan di Indonesia yaitu Palang Merah Indonesia (PMI) yang didukung dengan studi literatur. Data yang diperoleh kemudian akan dilakukan analisis menggunakan metode SWOT. Hasil: SWOT pada organisasi PMI kategori Strength (kekuatan) - Opportunities (kesempatan) meliputi cara mengembangkan potensi karyawan dan organisasi. Kategori Strength (kekuatan) - Threat (Ancaman) yaitu cara mengatur kerja masing-masing karyawan. Kategori Weakness (Kelemahan) Opportunities (Kesempatan) yaitu cara memberi penghargaan dan tingkat kepatuhan karyawan. Kemudian Weakness (Kelemahan) - Threat (Ancaman) yaitu cara mengevaluasi kinerja karyawan. Kesimpulan: Upaya optimal dan kesatuan visi msi setiap anggota organisasi sangat dibutuhkan demi tercapainya tujuan organisasi. Bahkan ancaman dan ancaman pun dapat menjadi kekuatan dan peluang suksesnya organisasi tersebut.
\end{abstract}

Kata Kunci: PMI, Kinerja SDM, Analisis SWOT

\begin{abstract}
PMI is a humanitarian organization that focuses on four key areas: disaster planning and management, volunteer first-aid training, health and community welfare services, and blood transfusion. The study is a descriptive analytic study with a nonexperimental design (Cross Sectional). According to the study's objectives, the research study's subject and population were based on an outline of one of Indonesia's health organizations, the Indonesian Red Cross (PMI), which was backed by literature studies. After that, the data will be examined using the SWOT method. Results: Results: SWOT in the PMI organization in the Strength - Opportunities category includes how to develop the potential of employees and the organization. Category
\end{abstract}


Strength - Threat is how to manage the work of each employee. Category Weakness Opportunities, namely how to reward and level of employee compliance. Then Weakness - Threat is a way to evaluate employee performance. Conclusion: To attain organizational goals, each member of the organization must put up maximum effort and share a common vision and mission. Even challenges and threats can be turned into assets and opportunities for the organization's development.

Keywords: PMI, Human Resource Performance, SWOT Analysis

\section{PENDAHULUAN}

Secara umum, organisasi merupakan sekelompok orang yang terdiri dari dua orang atau lebih, secara formal dan dipersatukan dalam sebuah kerjasama dalam mencapai tujuan yang telah ditetapkan bersama (1). Organisasi dibutuhkan oleh setiap manusia yang memiliki kepentingan dan juga tujuan yang sama, sebagai tempat atau badan dimana mereka saling berusahauntuk mewujudkan tujuan tersebut. Hal tersebut yang menjadi sebab adanya tujuan dari diadakannya sebuah organisasi yang kemudian bisa dikembangkan menjadi struktur organisasi.

Masa depan sebuah perusahaan sangat tergantung dengan tata kelola pada internal organisasinya. Organisasi harus terus berinovasi dalam menciptakan peluangpeluang bisnis yang semakin kompetitf. Untuk terus bertahan dalam konsep lama sudah tidak dapat digunakan dalam era milenial saat ini (2). Untuk itu struktur organisasi menjadi pondasi vital demi keberhasilan inovasi yang diharapkan.

\section{METODE PENELITIAN}

Penelitian ini merupakan penelitian deskriptif analitik dengan desain non eksperimental (Cross Sectional). Sesuai dengan tujuan penelitian, subjek dan populasi penelitian peneliti mengambil gambaran garis besar salah satu organisasi kesehatan di Indonesia yaitu Palang Merah Indonesia (PMI) yang didukung dengan studi literatur. Data yang diperoleh kemudian akan dilakukan analaisis menggunakan metode SWOT. 


\section{HASIL DAN PEMBAHASAN}

\section{HASIL}

\section{A. Nama Organisasi}

Organisasi yang saya pilih adalah Palang Merah Indonesia (PMI) yang merupakan sebuah organisasi perhimpunan nasional di Indonesia yang bergerak dalam bidang sosial kemanusiaan.

\section{B. Struktur Organisasi}

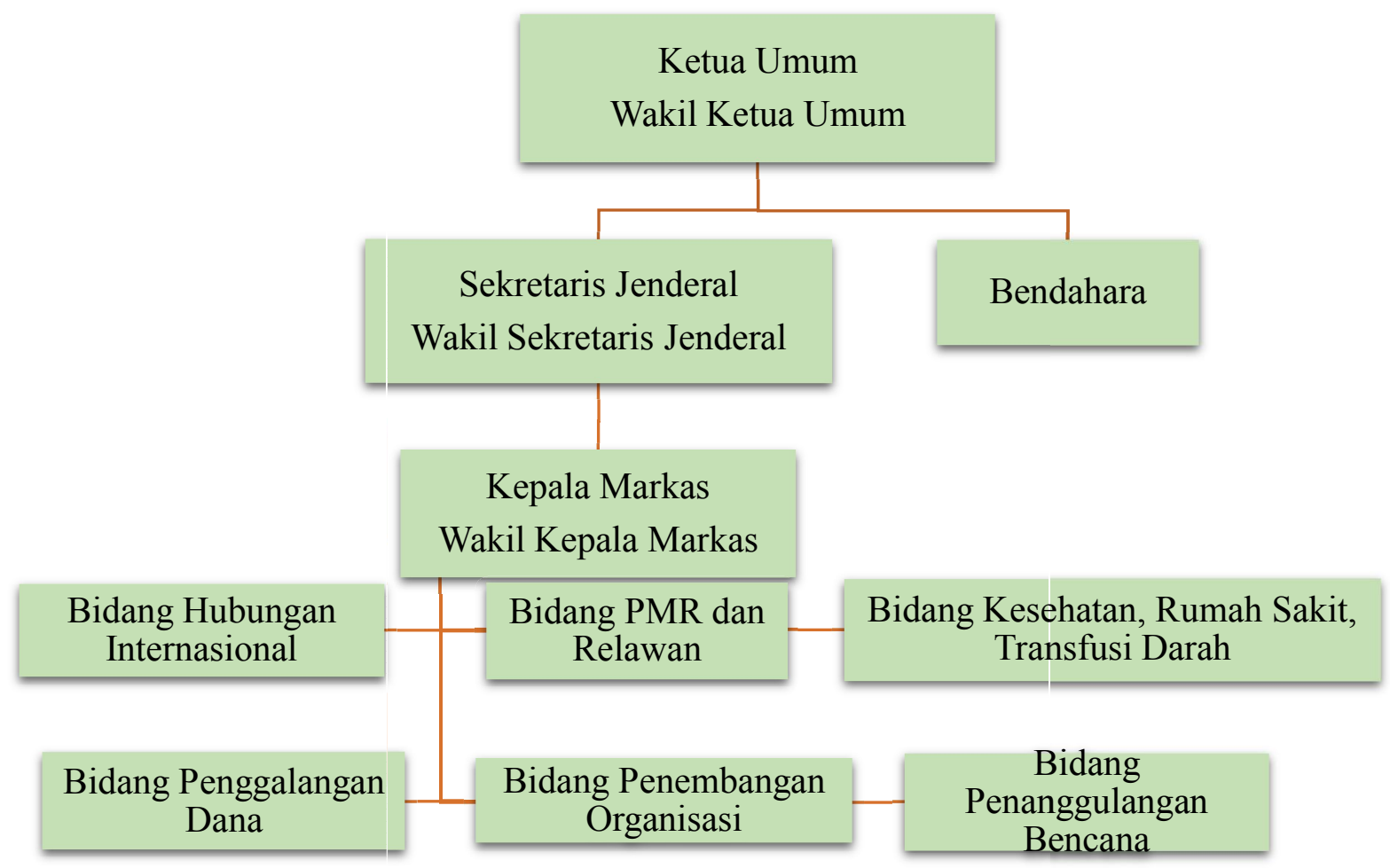

Gambar 1. Struktur Organisasi PMI 


\section{Bagan SWOT}

Tabel 1. Tabel SWOT Organisasi PMI

\begin{tabular}{|c|c|c|}
\hline Internal & Strength & Weakness \\
\hline Opportunities & $\begin{array}{l}\text { Cara Mengembangkan } \\
\text { Potensi Karyawan Dan } \\
\text { Organisasi }\end{array}$ & $\begin{array}{lr}\text { Cara } & \text { Memberi } \\
\text { Penghargaan } & \text { Dan } \\
\text { Tingkat } & \text { Kepatuhan } \\
\text { Karyawan } & \end{array}$ \\
\hline Threat & $\begin{array}{l}\text { Cara Mengatur Kerja } \\
\text { Masing-Masing } \\
\text { Karyawan }\end{array}$ & $\begin{array}{l}\text { Cara Mengevaluasi } \\
\text { Kinerja Karyawan }\end{array}$ \\
\hline
\end{tabular}

\section{PEMBAHASAN}

\section{Desain Organisasi}

\section{Bergerak di Bidang Apakah PMI itu?}

PMI adalah organisasi kemanusiaan yang berstatus badan hukum, diundangkan dengan Undang-Undang nomor 1 tahun 2018 tentang Kepalangmerahan guna menjalankan kegiatan Kepalangmerahan sesuai dengan Konvensi Jenewa Tahun 1949, dengan tujuan untuk mencegah dan meringankan penderitaan dan melindungi korban tawanan perang dan bencana, tanpa membedakan agama, bangsa, suku bangsa, warna kulit, jenis kelamin, golongan, dan Pandangan Politik (3)

\section{2.. Visi dan Misi Organisasi Palang Merah Indonesia (PMI)}

\section{Visi :}

a. Terwujudnya PMI yang Profesional dan Berintegritas serta Bergerak bersama Masyarakat

b. PMI yang berkarakter, profesional, mandiri dan dicintai masyarakat. 
c. PMI mampu dan siap menyediakan pelayanan kepalangmerahan dengan cepat dan tepat dengan berpegang teguh pada prinsip-prinsip dasar Palang Merah Internasional.

Misi :

a. Memelihara reputasi organisasi PMI di tingkat nasional daninternasional.

b. Menjadi organisasi kemanusiaan terdepan yang memberikan layanan berkualitas kepada masyarakat sesuai Prinsip-prinsip Dasar Gerakan Palang Merah dan Bulan Sabit Merah;

c. Meningkatkan integritas dan kemandirian organisasi melalui kerjasama strategis yang berkesinambungan dengan pemerintah, swasta, mitra gerakan, masyarakat dan pemangku kepentingan lainnya di semua tingkatan PMI dengan mengutamakan keberpihakan kepada masyarakat yang memerlukan bantuan.

\section{Tujuan Organisasi Palang Merah Indonesia (PMI)}

a. Mewujudkan PMI yang berfungsi baik di berbagai tingkatan, baik dalam pelaksanaan kebijakan, peraturan organisasi, sistem dan prosedur yang ditetapkan.

b. Meningkatkan kapasitas sumber daya organisasi PMI di berbagai tingkatan, baik sumber daya manusia dan sarana prasarana yang diperlukan dalam operasi penanganan bencana di seluruh wilayah Indonesia.

c. Meningkatkan ketahanan masyarakat untuk mengurangi risiko dan dampak bencana serta penyakit.

d. Meningkatkan pelayanan darah yang memadai, aman dan berkualitas di seluruh Indonesia.

e. Meningkatkan kemitraan yang berkesinambungan dengan sektor publik, swasta, mitra gerakan, lembaga donor dan pemangku kepentingan lainnya di semua tingkatan dalam melayanai masyarakat.

f. Meningkatkan akuntabilitas PMI sebagai organisasi kemanusiaan di tingkat Nasional maupun Internasional. 
g. Meningkatkan pemahaman seluruh elemen masyarakat tentang nilainilai kemanusiaan, prinsip-prinsip dasar Gerakan Internasional Palang Merah/Bulan Sabit Merah serta Hukum Perikemanusiaan Internasional melalui upaya komunikasi, edukasi dan diseminasi (3)

\section{Cara Mengatur Kerja Masing-Masing Karyawan}

\section{a. Membuat semua keputusan terkait pekerjaan berdasarkan kecakapan}

Untuk menghasilkan kinerja yang optimal dalam perusahaan dapat diukur dari hasil pekerjaan yang telah dilakukannya dibandingkan dengan standar yang telah ditetapkan oleh perusahaan, karena keberhasilan suatu organisasi dipengaruhi oleh kinerja karyawan. Kinerja merupakan hasil kerja yang dicapai oleh karyawan dalam melakukan tugas sesuai dengan tanggung jawabnya (4) .Tidak membatasi kontribusi berdasarkan umur, tanggung jawab pengurusan anak, disabilitas, suku, jenis kelamin, identitas jenis kelamin, orientasi seksual, agama, kehamilan, atau ciri-ciri pribadi lainnya yang dilindungi.

\section{b. Larangan tindakan kekerasan dan atau pelecehan}

Tingginya prevalensi kekerasan dalam rumah tangga (KDRT) dan penganiayaan anak memerlukan kerjasama antara organisasi kekerasan dalam rumah tangga (DVO) dan layanan perlindungan anak (CPS) untuk memenuhi kebutuhan keluarga. Sedikit yang diketahui tentang bagaimana karakteristik pekerja individu dan faktor tingkat agensi berinteraksi untuk memengaruhi kesediaan staf untuk berkolaborasi di antara kedua layanan ini (5)

\section{c. Menjadikan keselamatan sebagai prioritas}

Sikap organisasi terhadap kesalahan dapat ditelusuri kembali ke satu pertanyaan mendasar: haruskah kesalahan ditoleransi/diterima atau tidak? (6). Lindungi diri Anda sendiri dan orang-orang di sekitar Anda dari cedera dengan cara mematuhi semua peraturan kesehatan dari organisasi dan pemerintah, dan peraturan keselamatan dan keamanan. 


\section{d. Saling menghargai pendapat}

Salah satu bagian dari HAM adalah kebebasan menyampaikan pendapat. Pendapat merupakan usulan atau argumen yang disampaikan oleh tiap-tiap individu (7). Tidak memaksakan pendapat dan mendengar gagasan orang lain adalah norma dasar dalam berperilaku dalam organisasi. Semakin tinggi level anda diharapkan mampu menjadi pendengar dan problem solver yang baik, sehingga dapat dijadikan panutan oleh anggota organisasi yang lain.

\section{e. Hak mengeksplor bakat dan kemampuan}

Inovasi digital adalah kata kunci bagi organisasi di era saat ini untuk mendapatkan keunggulan kompetitif (8). Organisasi kita mendapatkan manfaat dari luasnya cakupan pendekatan dan opini. Kita mendukung lingkungan yang beragam dan inklusif di mana semua karyawan merasa nyaman. Kita semua memiliki kebutuhan dan gaya berbeda, dan kita harus melakukan penerimaan yang baik untuk menyesuaikan perbedaan ini.

\section{Cara Mengembangkan Potensi Karyawan Dan Organisasi}

Al-Khalifa dan Peterson (9) mengatakan bahwa kinerja karyawan akan meningkat jika karyawan merasa puas dalam pekerjaannya dan termotivasi untuk melakukan pekerjaan. Mehta, Dubinsky, dan Anderson (10) memberikan gambaran tentang kausalitas antara kepemimpinan, motivasi, dan kinerja karyawan.

Ada empat pendekatan motivasi, yaitu pendekatan tradisional, hubungan manusia, sumber daya manusia, dan pendekatan kontemporer. Dari empat pendekatan tersebut sangat dianjurkan untuk dilakukan dan merata jika ingin mengembangkan potensi kerja yang tinggi baik secara invidu maupun organisasi agar tujuan organisasi dapat tercapai dengan sempurna. Dengan demikian motivasi mempunyai peranan yang sangat penting dalam upaya peningkatan semangat kerja yang diharapkan pada setiap individu karyawan. 


\section{Cara Memberi Penghargaan Dan Tingkat Kepatuhan Karyawan}

Saat ini organisasi mencari cara yang lebih baik untuk membantu karyawan mereka menjadi lebih produktif dan menjadi lebih bahagia di tempat kerja mereka dengan tujuan tetap tinggi tingkat retensi. Karyawan ingin dihargai atas pekerjaannya upaya dan mereka mengharapkan pengembalian yang adil atas upaya itu juga. Organisasi menerapkan banyak strategi yang membuat karyawan lebih bahagia. Cara sistematis dari skema atau program yang memberikan insentif bagi individu atau kelompok tersebut yang berkinerja baik di perusahaan yang disebut sistem penghargaan (11)

\section{Cara Mengevaluasi Kinerja Karyawan}

Evaluasi dampak kapabilitas manajemen inovasi merupakan aspek penilaian penting terhadap kinerja organisasi (12):

a. Melakukan penilaian melalui KPI

Salah satu fungsi KPI adalah sebagai alat ukur kinerja karyawan. KPI mencatat rekaman target dan pencapaian individu, tim, maupun organisasi. Berdasarkan catatan tersebut, baik leader, manajer, dan HRD akan mampu menilai kinerja seorang karyawan dengan objektif karena terdapat indikator pencapaian didalamnya.

\section{b. Self-evaluation}

Membuat karyawan mengevaluasi dirinya sendiri juga merupakan salah satu cara dalam menilai kinerja karyawan. Self-evaluation memberikan ruang lebih lebar untuk menyatukan tujuan dan pencapaian individu dan organisasi. Bagi karyawan, menilai hasil kerja dan pencapaian sendiri akan meningkatkan rasa apresiasi dan engagement kepada organisasi. Begitu pun dengan organisasi, akan memiliki karyawan yang lebih memahami perkembangan dirinya sendiri berpotensi untuk meningkatkan kualitas kerja di kemudian hari.

c. Peer Feedback

Point of view orang ketiga selalu bisa membantu dalam bersikap objektif dan adil. Ini memberikan kesempatan unik untuk mempelajari keterampilan dan kemampuan karyawan dan membantu 
mengidentifikasi jaringan, kepemimpinan, pekerjaan, dan keterampilan kolaborasi individu dalam suatu organisasi.

d. Feedback $360^{\circ}$

Feedback $360^{\circ}$ juga mencakup review dari atasan maupun bawahan, bahkan dari pelanggan. Biasanya, feedback $360^{\circ}$ memberikan gambaran atas kinerja karyawan dalam lingkup kemampuan bekerja sama, kualitas kepemimpinan, orientasi tujuan, level motivasi, kemampuan beradaptasi, dan lain-lain.

\section{KESIMPULAN}

Palang Merah Indonesia (PMI) mempunyai empat tugas pokok yakni, kesiapsiagaan bantuan dan penanggulangan bencana, pelatihan pertolongan pertama untuk sukarelawan, pelayanan kesehatan dan kesejahteraan masyarakat, pelayanan transfusi darah sesuai dengan Peraturan Pemerintah No 18 Tahun 1980. Beberapa upaya dan program pengelolaan karyawan diharapkan mampu memberi kontribusi terbaik terhadap organisasi.

\section{DAFTAR PUSTAKA}

1. Organisasi, U. A. S. M. K., Organisasi FM. Pengorganisasian dan kepemimpinan. Pengorganisasian Dan Kepemimpinan, 181312651. 2011;(Mencapai, U., Organisasi, T., Pengorganisasian, A., Kunci, K., Pendahuluan, K.).

2. Ratnasari SL, , Dian Fitri, Zulkifli HWN dan S. ANALISIS MANAJEMEN PERUBAHAN, KEPEMIMPINAN TRANSFORMASIONAL, STRUKTUR ORGANISASI, BUDAYA ORGANISASI DAN DISIPLIN KERJA TERHADAP KINERJA KARYAWAN. J Benefita 5(2) Juli 2020. 2020;

3. Indonesia PM (n. d. . Sejarah Palang Merah Indonesia. Retrieved from http//pmi.or.id/.

4. Ainanur ST. Pengaruh Budaya Organisasi, Kompetensi dan Motivasi Terhadap Kinerja Karyawan. Maneggio J Ilm Magister Manaj. 2018; Vol 1, No.

5. K. Nikolova, J.L Postmusm C, Buttner EAB. Working together to protect women and children from domestic violence: Factors influencing willingness to collaborate between organizations. Child Youth Serv Rev. 2020;Volume 118.

6. Xingyu Wang, Priyanko Guchait AP. Tolerating errors in hospitality 
organizations: relationships with learning behavior, error reporting and service recovery performance. Int J Contemp Hosp Manag. 2020;Volume 32.

7. HAM K. Pemulihan Hak-Hak Korban Pelanggaran Hak Asasi Manusia ( Laporan Komnas HAM). Komisi Nas Hak Asasi Mns. 2016;(Jakarta,.

8. Georgia Moschogiann. Combined Effects of Self Tuning Model and Innovation Capability on Digital Innovation: A study of German Pharmaceutical Firm. J Digit Inf Syst. 2021; Vol 01 (01.

9. Al-Khalifa, A. K., \& Peterson S. On the relationship between initial motivation, and satisfaction and performance in joint ventures. Eur J Mark 30(2), 150-174. 2004;

10. Mehta, R., Dubinsky, A. J., \& Anderson RE. Leadership Style, Motivation and Performance in International Marketing Channel. New Jersey, USA: School of Management. Institute of Technology. 2003;

11. Armstrong M. Hand Book Of Employee Reward Management and Practices (2nd ed.). USA: Kogan Page Limited. 2007;

12. Javad Izadi Z.D., Sayabek Ziyadin, Maria Palazzo MS. The evaluation of the impact of innovation management capability to organisational performance. Qual Mark Res. 2020;Volume 23. 